\title{
Oncolytic activity of HF10 in head and neck squamous cell carcinomas
}

\author{
Shinichi Esaki $\mathbb{1}^{1,2} \cdot$ Fumi Goshima $^{1} \cdot$ Haruka Ozaki $^{1} \cdot$ Gaku Takano $^{1,2} \cdot$ Yoshimi Hatano $^{2}$ - Daisuke Kawakita ${ }^{2}$.

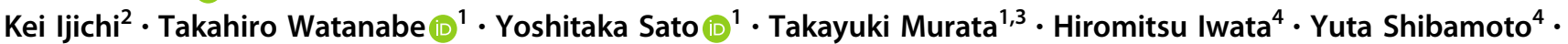 \\ Shingo Murakami ${ }^{2} \cdot$ Yukihiro Nishiyama $^{1} \cdot$ Hiroshi Kimura ${ }^{1}$
}

Received: 9 April 2019 / Revised: 3 June 2019 / Accepted: 7 June 2019 / Published online: 3 September 2019

(c) The Author(s), under exclusive licence to Springer Nature America, Inc. 2019

\begin{abstract}
Recent developments in therapeutic strategies have improved the prognosis of head and neck squamous cell carcinoma (HNSCC). Nevertheless, 5-year survival rate remains only 40\%, necessitating new therapeutic agents. Oncolytic virotherapy entails use of replication-competent viruses to selectively kill cancer cells. We aimed to explore the potential of HF10 as an oncolytic virus against human or mouse HNSCC cell lines, and primary-cultured HNSCC cells. HF10 replicated well in all the HNSCC cells, in which it induced cytopathic effects and cell killing. Next, we investigated the oncolytic effects of HF10 in ear tumor models with human or mouse tumor cells. We detected HF10-infected cells within the ear tumors based on their expression of green fluorescent protein. HF10 injection suppressed ear tumor growth and prolonged overall survival. In the syngeneic model, HF10 infection induced tumor necrosis with infiltration of CD8-positive cells. Moreover, the splenocytes of HF10-treated mice released antitumor cytokines, IL-2, IL-12, IFN-alpha, IFN-beta, IFN-gamma, and TNF-alpha, after stimulation with tumor cells in vitro. The HF10-treated mice that survived their original tumor burdens rejected tumor cells upon re-challenge. These results suggested that HF10 killed HNSCC cells and induced antitumoral immunity, thereby establishing it as a promising agent for the treatment of HNSCC patients.
\end{abstract}

These authors contributed equally: Shinichi Esaki, Fumi Goshima

Supplementary information The online version of this article (https:// doi.org/10.1038/s41417-019-0129-3) contains supplementary material, which is available to authorized users.

Shinichi Esaki

sesaki@med.nagoya-cu.ac.jp

$\triangle$ Fumi Goshima

fgoshima@med.nagoya-u.ac.jp

1 Department of Virology, Nagoya University Graduate School of Medicine, Nagoya, Japan

2 Department of Otolaryngology, Head and Neck Surgery, Nagoya City University Graduate School of Medical Sciences and Medical School, Nagoya, Japan

3 Department of Virology and Parasitology, Fujita Health University School of Medicine, Nagoya, Japan

4 Department of Radiology, Nagoya City University Graduate School of Medical Sciences and Medical School, Nagoya, Japan

\section{Introduction}

Head and neck cancer, includes cancers of the mouth, nose, sinuses, ear, salivary glands, throat, and lymph nodes in the neck. Head and neck cancer accounts for approximately 5\% of all cancers and is the 6th most common cause of cancerrelated death [1]. In 2017, head and neck cancer was estimated to affect more than 50,000 people and resulted in more than 10,000 deaths in the United States [2]. In Japan, 24,000 people were diagnosed with head and neck cancer and 8000 people died of head and neck cancer in 2012 [3]. Head and neck squamous cell carcinoma (HNSCC) accounts for more than $90 \%$ of head and neck cancers. Recent developments in therapeutic strategies, which include surgery, chemotherapy, and radiotherapy, have markedly improved outcomes for HNSCC patients. Despite current therapeutic strategies, the 5-year survival rate for HNSCC patients is only $40 \%$, necessitating the development of new therapeutic agents.

Oncolytic viruses are genetically engineered or naturally occurring viruses that can infect and kill malignant cells while sparing surrounding normal cells. The concept for 
oncolytic virotherapy is based on clinical reports of cancer regression caused by viral infection [4]. Recently, oncolytic virotherapy has been recognized as a promising new therapeutic approach for cancer treatment. In 2015, the U.S. Food and Drug Administration approved the first oncolytic herpes simplex virus (HSV), talimogene laherparepvec (TVEC), for the treatment of advanced inoperable malignant melanoma [5]. In an open-label phase III trial, intratumoral treatment with T-VEC resulted in a significantly higher durable response rate, overall response rate, and median overall survival than treatment with GM-CSF [6]. Moreover, direct injection of T-VEC induces local and systemic antigen-specific $\mathrm{T}$-cell responses and decreases immune suppression in therapy-responsive patients [7].

Oncolytic virotherapy is a candidate therapy for patients with HNSCC as, like malignant melanoma, HNSCC is amenable to intratumoral injection. HSV has many advantages over other viruses for oncolytic virotherapy [8]. First, it has a broad host range and high efficiency of infection of both replicating and nonreplicating cells. Second, HSV can be engineered to deliver even large transgenes because of its large genomic capacity. Preclinical evaluation using small animals is easy because HSV infects mice, guinea pigs, and monkeys. HSV infections can be controlled by antiherpetic drugs. Furthermore, most of the disease-related genes in HSV have been identified. First human studies have shown virus replication and oncolytic effects against HNSCC tumors upon intratumoral injection of the oncolytic HSVs, HF10 (now called canerpaturev) [9] and HSV1716 (now called seprehvir) [10]. Thereafter, previously untreated HNSCC patients showed favorable responses to T-VEC in combination with radiotherapy and cisplatin in a phase I/II trial in the United Kingdom [11]. In the United States, a phase I trial of HSV1716 in patients with noncentral nervous system solid tumors (NCT00931931) and a phase I/II trial of HF10 in patients with refractory head and neck cancer or solid cutaneous tumors have been conducted (NCT01017185). In that trial, $33 \%$ of the patients had stable disease (SD), and some showed a reduction in tumor size and fewer adverse events compared with those treated with T-Vec [12]. A phase II study of HF10 and ipilimumab, an anti-CTLA-4 immune checkpoint inhibitor, is ongoing for melanoma in the United States and Japan (NCT02272855 and NCT03153085).

Before these clinical trials, mouse models were used to investigate oncolytic activity. Most previous preclinical studies used human HNSCC cell lines implanted into the flank of immunodeficient mice [13-21], or murine SCC-VII cells [22-25]; however, they did not investigate the immune response. Furthermore, no study to date has used primarycultured cells obtained from surgical specimens. In the current study, we investigated the oncolytic activity of HF10 on HNSCC in vitro and in vivo using cell lines and cultured primary cells. Thereafter, we investigated local and systemic HF10-induced antitumor immunity in a syngeneic mouse model.

\section{Materials and methods}

\section{Animals}

Six-week-old specific-pathogen-free female $\mathrm{C} 3 \mathrm{H} / \mathrm{HeJ}$ mice and BALB/c-nu/nu mice (Japan SLC, Hamamatsu, Japan) were used as syngeneic and immunodeficient mice, respectively. All mice were given food and water ad libitum. All experiments were approved by the University Committee in accordance with the Guidelines for Animal Experimentation at Nagoya University.

\section{Virus}

HF10 is a nonselected clone derived from the naturally occurring attenuated HSV type 1 strain HF [26]. The properties of HF10 have been previously described [27]. HF10 was propagated in Vero cells, then stored as aliquots at $-80^{\circ} \mathrm{C}$. Viral titers (plaque-forming units $[\mathrm{pfu}] / \mathrm{mL}$ ) were determined by plaque assays in Vero cells. To facilitate the visualization of HF10 infection, the green fluorescent protein (GFP) gene was inserted into HF10 under the control of the cytomegalovirus promoter, resulting in the strain HF10-GFP [28].

\section{Cells}

Two human HNSCC cell lines, $\mathrm{FaDu}$ and Detroit 562 cells (CCL\# HTB-43 and CCL-138), were obtained from the American Type Culture Collection (Rockville, MD, USA). $\mathrm{FaDu}$ cells were derived from human hypopharynx cancer and Detroit 562 cells were derived from human pharynx cancer. Both cell lines were negative for human papilloma virus (HPV) [29]. SCC-VII cells, a squamous cell carcinoma line derived from a $\mathrm{C} 3 \mathrm{H}$ mouse, were kindly provided by $\mathrm{Dr}$. Shibamoto at Nagoya City University [30, 31]. African green monkey kidney cells (Vero cells) were obtained from Riken Cell Bank (Tsukuba, Japan). FaDu, Detroit 562, and SCC-VII cells were maintained in Eagle's minimum essential medium (EMEM; Nissui Pharmaceutical, Tokyo, Japan) containing $10 \%$ fetal bovine serum (FBS) (GE Healthcare Life Sciences, South Logan, UT, USA) and the antibiotics penicillin-streptomycin (Sigma-Aldrich, St. Louis, MO, USA) at $37{ }^{\circ} \mathrm{C}$ in $5 \% \mathrm{CO}_{2}$. Vero cells were grown in EMEM containing $10 \%$ calf serum (GE Healthcare Life Sciences) and antibiotics. All commercial cells were obtained was passaged for fewer than 6 months after receipt or resuscitation.

Patient-derived HNSCC cell lines, NSCC-1F and NSCC$2 \mathrm{~F}$, were isolated from surgical specimens of 
hypopharyngeal squamous cell carcinomas. Tissue collection and culture were approved by the Institutional Review Board at Nagoya City University Hospital. To establish the human HNSCC lines, minced tissues were digested with $0.1 \%$ trypsin at $37^{\circ} \mathrm{C}$ for $30 \mathrm{~min}$, washed with Hank's balanced salt solution, and cultured in Dulbecco's modified Eagle's medium (DMEM; Wako Pure Chemical Industries, Osaka, Japan) supplemented with 10\% FBS and antibiotics.

Mouse-derived HNSCC cell lines, TC4T + and TC5s, were isolated from the tongue tumor of a $\mathrm{C} 3 \mathrm{H}$ mouse after multiple injections of 4-nitroquinoline 1-oxide (Wako Pure Chemical Industries). The tongue tumor was removed, minced, and digested with $0.5 \%$ trypsin at $37^{\circ} \mathrm{C}$ for $15 \mathrm{~min}$. After they were washed with phosphate-buffered saline (PBS), the cells were cultured in DMEM supplemented with $10 \%$ FBS and antibiotics.

All primary cell lines were used for experiments before passage 10. All cells were routinely tested for mycoplasma using TaKaRa PCR Mycoplasma Detection Set (Takara Bio, Kusatsu, Japan). Tumorigenicity was confirmed when implanted subcutaneously into the flank of nude mice.

\section{HPV and Epstein-Barr virus status of human HNSCC cells}

We extracted DNA from the human squamous cell carcinoma cell lines (FaDu, Detroit 562, NSCC-1F, and NSCC2F cells) using ISOGENOME (Nippon Gene, Toyama, Japan). HPV status was examined using the HPV primers in the TaKaRa PCR Human Papillomavirus Typing Set (Takara Bio) with a CFX96 Touch $^{\mathrm{TM}}$ Real-Time PCR Detection System (Bio-Rad Laboratories, Hercules, CA, USA). The Epstein-Barr virus (EBV) statuses of the cells were examined, as previously reported [32].

\section{Cytotoxicity assay}

The cells were seeded in 96-well plates $\left(1 \times 10^{4}\right.$ cells/well). The next day, they were infected with HF10 at various multiplicities of infection (MOIs). After $72 \mathrm{~h}$ of infection, we measured cell viability in an MTS assay with CellTiter $96{ }^{\circledR}$ AQueous One Solution Reagent (Promega, Fitchburg, WI, USA) according to the manufacturer's instructions. Cytotoxicity was expressed as the decrease in viability of the cells subjected to each treatment relative to the viability of the mock-infected cells. All assays were performed in triplicate.

\section{Replication assay}

The cells were plated on $35-\mathrm{mm}$ dishes $\left(2 \times 10^{5}\right.$ cells/dish in $2 \mathrm{~mL}$ EMEM). The next day, the cells were infected with HF10 at an MOI of 3 or 0.03 . To examine the time course of viral production from infected cells, we collected supernatants at the indicated time points. Then, we determined the viral titers by plaque assays in Vero cells. Cell images were obtained with a microscope (Olympus, Tokyo, Japan) with a CCD camera system.

\section{Mouse xenograft models of ear cancer}

FaDu cells $\left(1 \times 10^{6}\right.$ cells $\left./ 20 \mu \mathrm{L}\right)$ were injected into the right ear auricles of nude mice $(n=10)$. After 3 days, when the tumors were palpable (approximately $2 \mathrm{~mm}$ in diameter), the mice were randomly divided into mock and HF10 groups. On days 3 and 6 , HF10 $\left(1.5 \times 10^{6} \mathrm{pfu} /\right.$ $20 \mu \mathrm{L})$ or PBS $(20 \mu \mathrm{L})$ was inoculated into the right ear tumor. The general conditions of the mice were monitored daily and tumor diameter was measured with an external caliper twice per week. The mice were sacrificed when their tumors exceeded $15 \mathrm{~mm}$ in diameter or became ulcerated.

\section{Syngeneic mouse model of ear cancer}

SCC-VII cells $\left(2 \times 10^{5}\right.$ cells $\left./ 20 \mu \mathrm{L}\right)$ were injected into the right ear auricles of the $\mathrm{C} 3 \mathrm{H}$ mice $(n=10)$. When the tumors were palpable (day 4), the mice were randomly divided into mock and HF10 groups. On days 4 and 7, HF10 $\left(1.5 \times 10^{6} \mathrm{pfu} / 20 \mu \mathrm{L}\right)$ or PBS $(20 \mu \mathrm{L})$ was inoculated into the right ear tumor. The general conditions were monitored daily and tumor diameter was measured twice per week. The mice were sacrificed when their tumors exceeded $15 \mathrm{~mm}$ in diameter or became ulcerated.

To investigate the induction of antitumor immunity, HF10-pretreated mice $(n=3)$ and naïve $\mathrm{C} 3 \mathrm{H}$ mice $(n=3)$ were subcutaneously inoculated on their right flanks with SCC-VII cells $\left(1 \times 10^{6}\right.$ cells $\left./ 100 \mu \mathrm{L}\right)$. Tumors were measured twice per week; tumor volume was calculated using the formula: $(\pi \times$ short axis $\times$ long axis $\times$ height $) / 6$. The mice were sacrificed when their tumors exceeded $20 \mathrm{~mm}$ in diameter.

\section{Localization of virus-associated GFP expression in mice}

To visualize the spread of HF10 in the tumor masses, $\mathrm{FaDu}$ cells $\left(1 \times 10^{6}\right.$ cells $\left./ 20 \mu \mathrm{L}\right)$ or SCC-VII cells $\left(2 \times 10^{5}\right.$ cells/ $20 \mu \mathrm{L}$ ) were injected into the right ear auricles of mice. When the diameter of a tumor reached $5 \mathrm{~mm}$, HF10-GFP $\left(1.5 \times 10^{6} \mathrm{pfu} / 20 \mu \mathrm{L}\right)$ or PBS $(20 \mu \mathrm{L})$ was inoculated into the right ear tumor. GFP-expressing cells were visualized under anesthesia by chloral hydrate $(360 \mathrm{mg} / \mathrm{kg}) 24 \mathrm{~h}$ after infection using a fluorescence stereomicroscope with a standard GFP filter set (Leica Mikrosysteme Vertrieb, Wetzlar, Germany). 


\section{Histopathological and immunohistochemical analysis}

To examine the oncolytic effects of HF10 and the infiltrating immune cells in the tumors, SCC-VII tumors were histologically analyzed after injections of HF10 or PBS on days 4 and 7. Twenty-four hours after the final injection, the ear tumors were removed under anesthesia by chloral hydrate and soaked in $10 \%$ buffered formalin. Paraffinembedded tissues were sectioned $(3 \mu \mathrm{m})$ serially using a microslicer. Serial sections were subjected to hematoxylin and eosin (H\&E) staining as well as immunohistochemical staining, as previously described [33-36]. In brief, $\mathrm{H} \& \mathrm{E}$ staining was performed using conventional Mayer's H\&E stain. The following primary antibodies were used for immunohistochemical staining: rat monoclonal anti-CD4 antibody (R\&D Systems, Minneapolis, MN, USA), rabbit monoclonal anti-CD8, (Burlingame, CA, USA), rabbit polyclonal anti-HSV-1 antibody (Dako A/S, Glostrup, Denmark), and rat monoclonal anti-F4/80 antibody (Santa Cruz Biotechnology, Santa Cruz, CA, USA). Then, the following secondary antibodies were used: goat anti-rabbit immunoglobulin conjugated to peroxidase-labeled dextran polymer (Dako A/S) or goat anti-rat immunoglobulin conjugated to peroxidase-labeled dextran polymer (Nichirei, Tokyo, Japan), both of which were visualized with the chromogenic indicator dye DAB+ (Dako A/S). Antibody specificity was confirmed using a universal negative control immunoglobulin (Dako A/S), and the staining was confirmed in slides of the spleen. Images of the serial sections were obtained by the microscopy (Olympus Corp.).

\section{Antitumor and immune-stimulatory cytokine secretion in tumors}

To investigate secreted cytokines in the tumors, we removed SCC-VII tumors under anesthesia by chloral hydrate 3 and $24 \mathrm{~h}$ after the second injections of HF10 or PBS on day 7. The tumors $(n=3)$ were weighed, rinsed with PBS, soaked in $5 \mathrm{~mL} / \mathrm{mg}$ cold PBS with Protease Inhibitor Mix (GE Healthcare, Little Chalfont, UK), and sonicated on ice. The levels of IL-2, IFN- $\gamma$, and TNF- $\alpha$ were measured by ELISA with the Quantikine Mouse IL-2 Immunoassay, Quantikine Mouse IFN- $\gamma$ Immunoassay, and Quantikine Mouse TNF- $\alpha$ Immunoassay (R\&D Systems), according to the manufacturer's instructions.

\section{Flow cytometric analysis of splenic leukocytes}

To analyze systemic immune responses, we removed spleens at the same time as SCC-VII tumors on day 8 . The splenocytes were isolated, halved, and subjected to flow cytometry. After lysis of red blood cells with Pharm Lyse ${ }^{\mathrm{TM}}$
(Biosciences Pharmingen, San Diego, CA, USA), splenocytes were washed twice with $1 \mathrm{~mL}$ PBS containing $0.5 \%$ FBS and incubated for $20 \mathrm{~min}$ in the dark with $0.25 \mu \mathrm{g}$ of the following antibodies diluted in PBS: fluorescein isothiocyanate-conjugated anti-mouse CD45 (clone 30F11), PerCP/Cy5.5-conjugated anti-mouse CD11b (clone M1/70), PerCP/Cy5.5-conjugated anti-mouse CD3 (clone 17A2), R-phycoerythrin (PE)-conjugated anti-mouse CD4 (clone GK1.5), PE-conjugated anti-mouse CD45R/B220 (clone RA3-6B2), Alexa Fluor ${ }^{\circledR}$ 647-conjugated anti-mouse Gr-1 (clone RB6-8C5), Alexa Fluor ${ }^{\circledR}$ 647-conjugated antimouse CD8a (clone 53-6.7), and Alexa Fluor ${ }^{\circledR}$ 647conjugated anti-mouse CD49b (clone HMa2) (all purchased from BioLegend, San Diego, CA, USA). After two washes with $\mathrm{PBS}$, the $\mathrm{CD} 45^{+}$-gated lymphocytes were analyzed by flow cytometry using a FACSCanto II (BD Biosciences, Franklin Lakes, NJ, USA).

\section{Antitumor and immune-stimulatory cytokine release by splenocytes co-cultured with SCC-VII cells}

The SCC-VII cells were plated on $35-\mathrm{mm}$ dishes $\left(2 \times 10^{5}\right.$ cells/dish in $2 \mathrm{~mL}$ of EMEM) on the previous day, and the rest of the splenocytes were co-cultured with SCC-VII cells (20:1) for 24 or $72 \mathrm{~h}$. We measured the cytokines released into the supernatants with the VeriKine Mouse Interferon Alpha ELISA Kit, VeriKine Mouse Interferon Beta ELISA Kit (PBL Assay Science, Piscataway, NJ, USA), Quantikine Mouse IL-2 Immunoassay, Quantikine Mouse IFN- $\gamma$ Immunoassay, and Quantikine Mouse TNF- $\alpha$ Immunoassay and Quantikine Mouse IL-12 p70 Immunoassay (R\&D Systems), according to the manufacturer's instructions.

\section{Statistical analysis}

The data were analyzed using JMP for Windows version 10.0.2 (SAS Institute, Cary, NC, USA) and are shown as the mean \pm SEM. The tumor diameters and volumes were analyzed using two-way factorial ANOVA. The survival data were analyzed using the Kaplan-Meier method and the log-rank test. The remaining data were analyzed by unpaired Student's $t$-test. Differences with a probability value of $p<0.05$ were considered statistically significant.

\section{Results}

\section{HF10 killed human and mouse HNSCC cells in vitro}

First, we examined the HPV and EBV statuses of the human HNSCC cells. No human HNSCC cells used in this study were positive for HPV or EBV (Supplementary Table 1). Next, we investigated the oncolytic activity of HF10 on 


\section{Human cell lines}

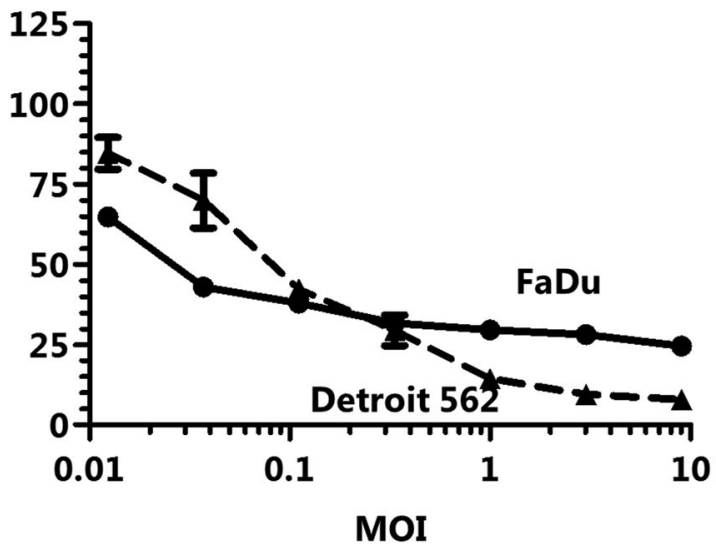

Human tumor-derived cells

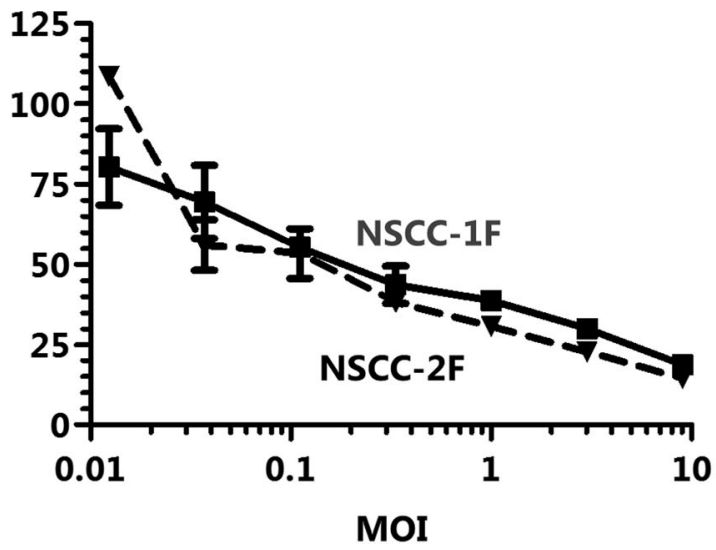

Fig. 1 HF10 killed human and mouse HNSCC cells in vitro. The indicated cells were infected with $\mathrm{HF} 10$ at various MOIs and viability was assessed at $72 \mathrm{~h}$ post infection. Cell viability, calculated from the

human HNSCC cell lines. At $72 \mathrm{~h}$ post infection, HF10 killed the human HNSCC cell lines FaDu and Detroit 562 in an MOI-dependent manner (Fig. 1). SCC-VII is a squamous cell carcinoma line derived from a $\mathrm{C} 3 \mathrm{H}$ mouse [37]. Although SCC-VII cells were derived from the abdominal wall, they were the only murine cells available. Also, subcutaneous implantation of SCC-VII cells is the most frequently used syngeneic transplantation model of HNSCC [38, 39]. HF10 also killed SCC-VII in an MOI-dependent manner (Fig. 1). To confirm the oncolytic activity on the HNSCC tumors, we isolated and cultured human HNSCC cells, called NSCC-1F and NSCC-2F, from surgical hypopharyngeal carcinoma specimens. We also isolated and cultured mouse HNSCC cells, called TC4T + and TC5s, from two surgical specimens of a tongue tumor that arose after multiple injections of 4-nitroquinoline 1-oxide, a chemical oral carcinogen [40]. HF10 killed all cultured primary HNSCC cells in an MOI-dependent manner (Fig. 1).
Mouse cell lines

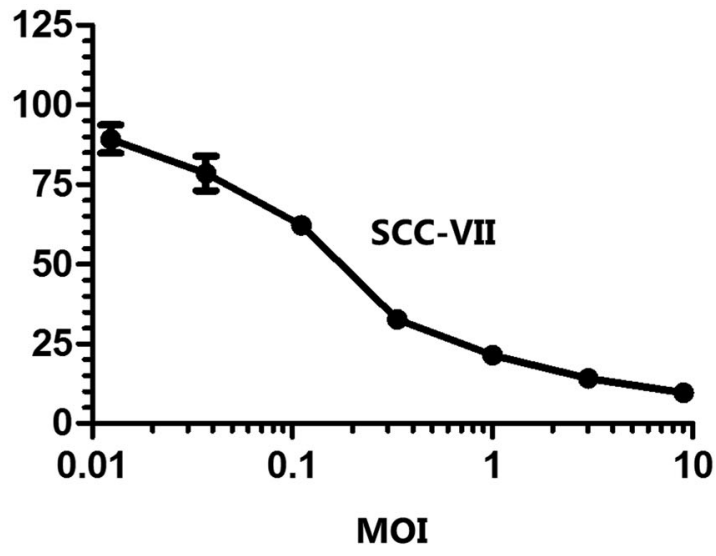

Mouse tumor-derived cells

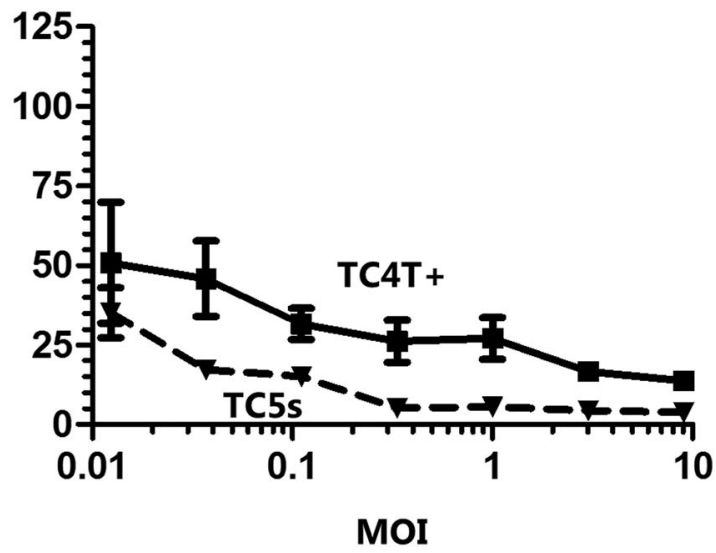

mean of samples tested in triplicate, is presented as the percent of live cells in the test group relative to in the uninfected control

\section{HF10 replicated well in human and mouse HNSCC cells}

Next, we examined the replication of HF10 in HNSCC cells. We infected all HNSCC cells with HF10 at an MOI of 3 to investigate one-step virus growth. Vero cells were infected as a positive control. HF10 replicated well in all HNSCCs. Next, we infected the HNSCC cells at an MOI of 0.03 to investigate multistep virus growth. HF10 also replicated well after infection at the lower MOI in all HNSCCs. During the replication assay, cytopathic effects (CPEs) were observed in FaDu, SCC-VII, and Vero cells (Fig. 2) and the other HNSCC cells (data not shown).

\section{HF10 treatment inhibited FaDu ear tumor growth and prolonged overall survival}

Then, we investigated the oncolytic effects of HF10 in a xenograft tumor model. In this study, we established a head 


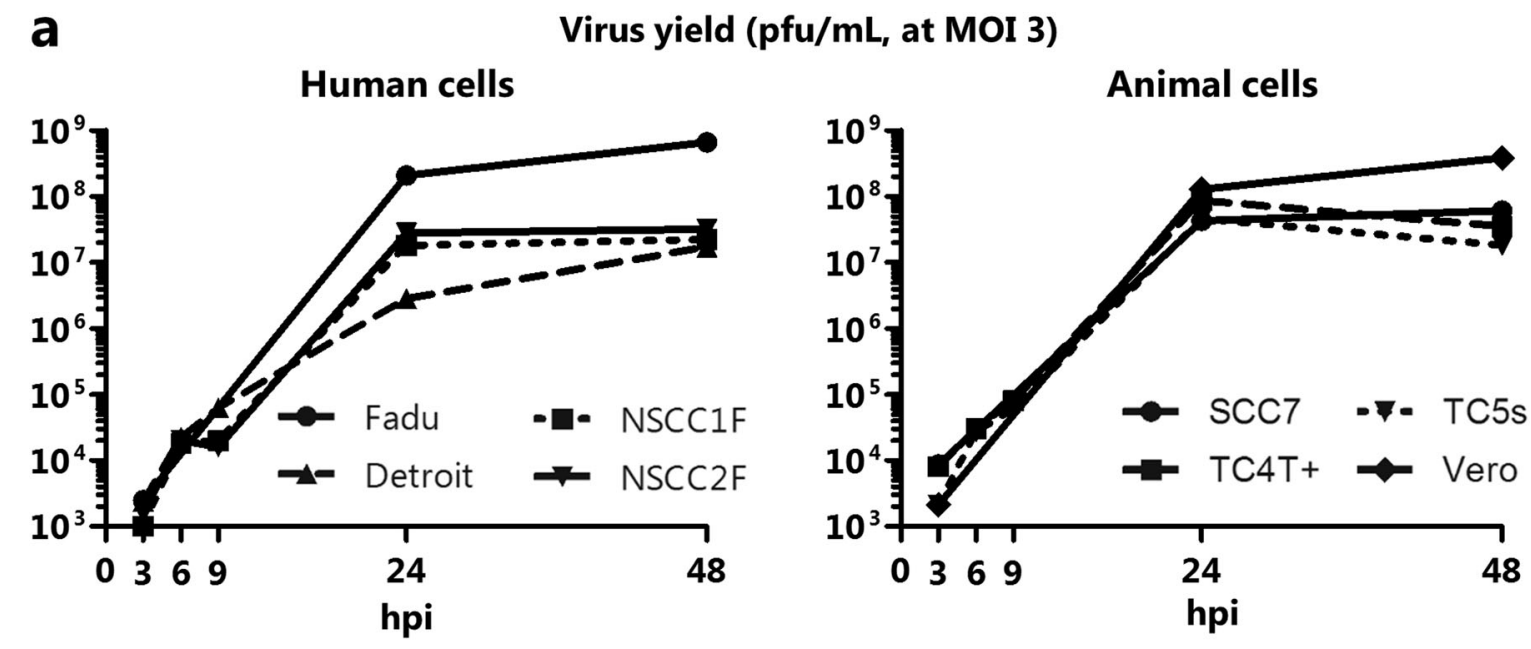

Virus yield (pfu/mL, at MOI 0.03)

Human cells

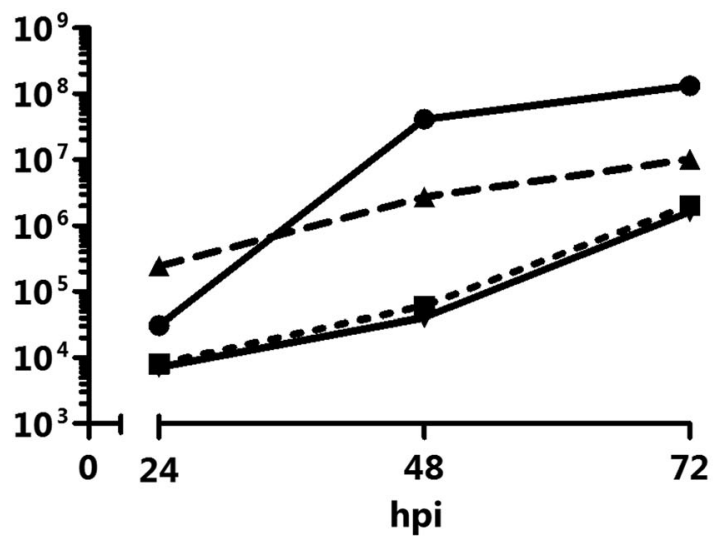

b

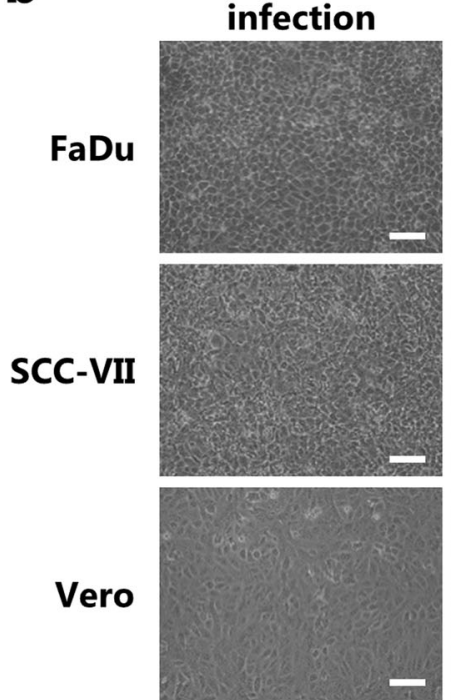

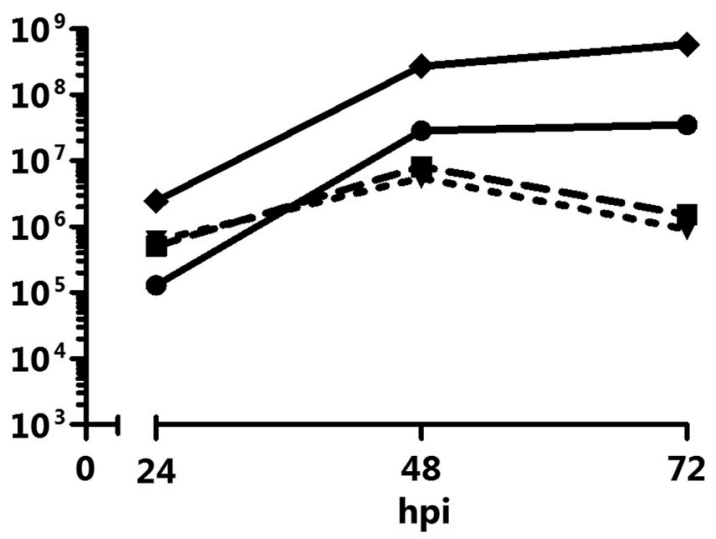

$48 \mathrm{hpi}$ at MOI 0.03
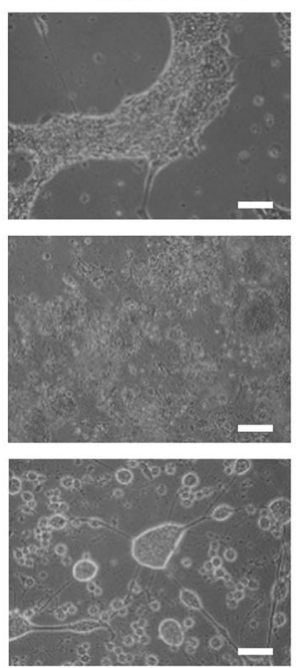

Fig. 2 HF10 replicated in human and mouse HNSCC cells and induced CPEs. a One-step (MOI = 3) and multistep (MOI $=0.03)$ growth curves of HF10 in the indicated cells. b Representative images of FaDu, SCC-VII, and Vero cells after HF10 infection (MOI = 3 or 0.03 ). Scale bars, $50 \mu \mathrm{m}$ 
a

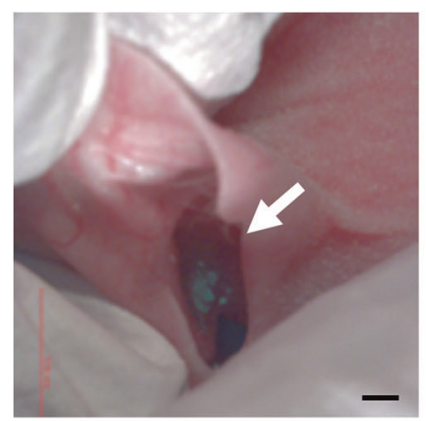

C

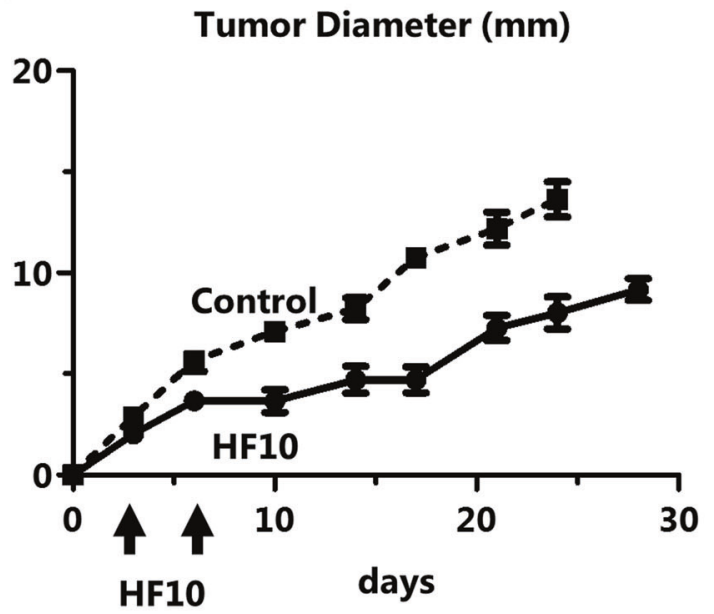

e

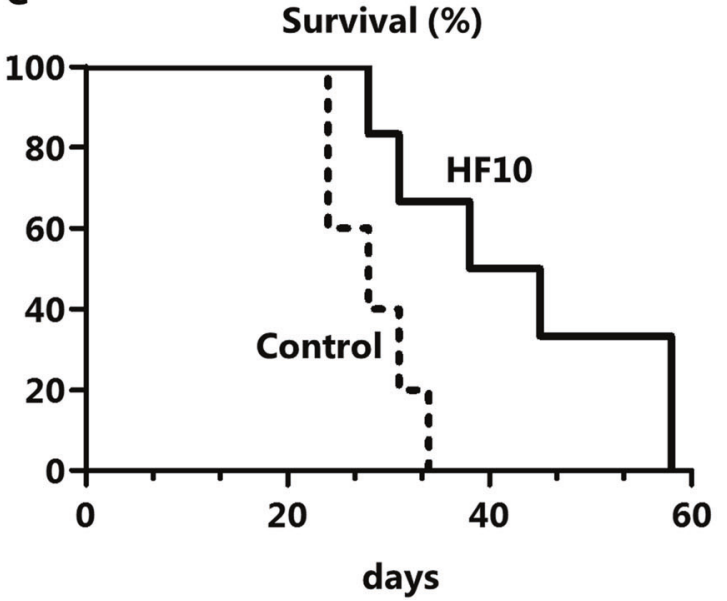

Fig. 3 HF10 suppressed the growth of FaDu ear tumors. a HF10-GFP was injected into FaDu ear tumors. GFP-positive cells were observed at $24 \mathrm{~h}$ after injection. The tumor is indicated by the arrow. Scale bars, $1 \mathrm{~mm}$. b Photographs of the mice on day 14 after control or HF10

and neck tumor model using FaDu cells, which formed the biggest tumor of the four human HNSCC cell lines when injected subcutaneously in a preliminary experiment (data not shown). We injected $\mathrm{FaDu}$ cells into the right ear auricles of nude mice on day 0 . We observed tumor masses in all mice on day 3. To observe viral spread, we injected HF10-GFP into b
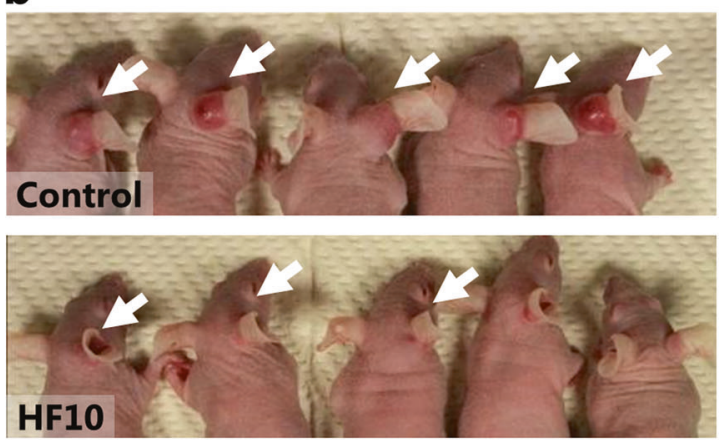

d

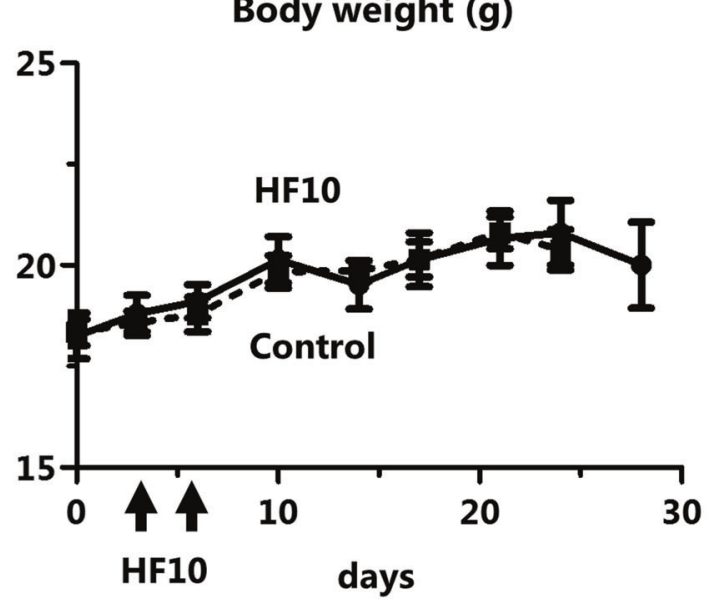

treatment. The arrows indicate the ear tumors. c-e HF10 or PBS was intratumorally injected on days 3 and 6 after tumor inoculation $(n=5)$. HF10 injection suppressed tumor growth $(p<0.001)$ and significantly prolonged survival $(p<0.01)$

the $\mathrm{FaDu}$ tumors on day 6 . At $24 \mathrm{~h}$ after the injection, we observed GFP-positive cells in the ear tumors (Fig. 3a). Next, we investigated the antitumor activity of HF10 in vivo. HF10 or PBS was injected into the ear tumors on days 3 and 6 . On day 14, all control mice had ear tumors; all HF10-injected mice had smaller tumors than those in the control mice 
(Fig. 3b). HF10 treatment significantly reduced tumor diameter and prolonged overall survival without causing weight loss (Fig. 3c-e) or major complications $(p<0.001)$.

\section{HF10 treatment suppressed SCC-VII ear tumor growth, prolonged overall survival, and promoted the rejection of subcutaneous tumors upon rechallenge}

Then, we used a syngeneic ear tumor model to investigate antitumor immunity. We injected SCC-VII cells into the right auricles of the ears of $\mathrm{C} 3 \mathrm{H}$ mice on day 0 . We observed tumor masses in all mice on day 4. We injected HF10-GFP into the SCC-VII tumors on day 7. GFP-positive cells in the tumors were observed $24 \mathrm{~h}$ after injection (Fig. 4a). Next, we injected HF10 or PBS into the ear tumors on days 4 and 7. On day 17 , all control mice had ear tumors; however, after two injections of HF10, the ear tumors were smaller in 2 of 5 mice than in the controls and were absent from the other 3 mice (Fig. 4b). HF10 treatment significantly reduced tumor diameter and prolonged the survival of the mice without inducing weight loss (Fig. 4c-e) or major complications $(p<$ 0.001). Three HF10-treated mice completely rejected the tumors and survived for more than 4 months.

Then, we investigated if antitumor immunity was induced after HF10 treatment. We subcutaneously injected SCC-VII cells into the three mice that rejected their tumors after HF10 treatment. As a control, we subcutaneously injected SCC-VII cells into three naïve mice that had not previously been injected with tumor cells. Although subcutaneous tumors grew in all naïve mice, no subcutaneous tumors were observed in the HF10-pretreated mice. The complete rejection of the SCC-VII cells indicated the development of acquired antitumor immunity after HF10 treatment.

\section{HF10 treatment-induced tumor necrosis and $\mathrm{CDB}^{+}$ T-cell infiltration in and around the tumor, suppressed tumor growth, and promoted IL-2, IFN- $Y$, and TNF-a secretion}

To investigate the oncolytic effects and immune responses induced by HF10, we pathologically examined the SCC-VII ear tumors after treatment. Twenty-four hours after the second injections of HF10 or PBS, HF10 injection induced tumor necrosis, whereas PBS injection did not (Fig. 5a). HSV-infected cells were detected in and around the necrotic area only after HF10 injection. $\mathrm{CD}^{+} \mathrm{T}$ cells accumulated around the necrotic area and inside and at the edge of the ear tumor after HF10 injection, but not after PBS injection. However, no $\mathrm{CD}^{+}{ }^{+} \mathrm{T}$ cells or $\mathrm{F} 4 / 80^{+}$macrophages were detected in either group (data not shown).

Then, we investigated antitumor and immunestimulatory cytokine production in the tumor. At 3 and
$24 \mathrm{~h}$ after the second injections, ear tumors were removed and weighed ( $n=3$ each). Both at 3 and $24 \mathrm{~h}$, tumor weight was significantly lower in the HF10 treatment group than in the PBS group (Fig. 5b). Moreover, HF10 treatment significantly increased immunostimulatory IL-2 and antitumor IFN- $\gamma$ and TNF- $\alpha$ production in the tumor compared with the levels in the controls at 3 and $24 \mathrm{~h}$ after treatment (Fig. $5 b)$. At $24 \mathrm{~h}$, the level of IL-2 remained high, but the levels of IFN- $\gamma$ and TNF- $\alpha$ were lower than at $3 \mathrm{~h}$.

\section{HF10 treatment-induced $\mathrm{CDB}^{+} \mathrm{T}$ cell and granulocyte accumulation in the spleen}

To investigate systemic immune responses, we collected the spleens of the mice for histopathological examination. We analyzed $\mathrm{CD} 45^{+}$splenocytes by flow cytometry (Fig. 6a). HF10 treatment significantly increased $\mathrm{CD}^{+} \mathrm{T}$ cell and $\mathrm{Gr}-$ $1^{+} \mathrm{CD} 11 \mathrm{~b}^{-}$granulocyte counts in the spleen compared with counts after control treatment. HF10 treatment also increased $\mathrm{CD}^{+}{ }^{+}$pan- $\mathrm{T}$ cell, $\mathrm{CD} 4^{+} \mathrm{T}$ cell, B220 ${ }^{+} \mathrm{B}$ cell, and $\mathrm{CD}_{49} \mathrm{~b}^{+} \mathrm{CD}^{-}$natural killer cell counts compared to control treatment, but the increases did not reach statistical significance.

\section{Antitumor and immune-stimulatory cytokine secretion by splenocytes co-cultured with tumor cells}

To investigate the induction of antitumor immunity, we co-cultured splenocytes from tumor-challenged mice with SCC-VII cells. After $24 \mathrm{~h}$ of co-culture, the levels of the major antitumor cytokines IFN- $\alpha$, IFN- $\beta$, IFN- $\gamma$, and TNF- $\alpha$ produced by HF10-treated splenocytes were significantly higher than the levels in the cultures of the control-treated splenocytes (Fig. 6b, c). Furthermore, the levels of the immune-stimulatory cytokines IL-2 and IL12 were significantly higher in the HF10-treated group than in the control group. Our previous studies demonstrated that increased production of IFN $-\gamma$ and TNF- $\alpha$ after $72 \mathrm{~h}$ of co-culture contributed to enhanced antitumoral immunity $[35,36]$. Although the level of IFN- $\gamma$ was lower at 72 than $24 \mathrm{~h}$, the levels of IFN- $\gamma$ and TNF- $\alpha$ produced by HF10-treated splenocytes remained significantly higher than those produced by control splenocytes (Fig. 6c). When the splenocytes were cultured without SCC-VII cells, the levels of all cytokines were below the limit of detection.

\section{Discussion}

Most patients with HNSCC present with advanced stage III/ IV disease with high incidences of local and regional 
a

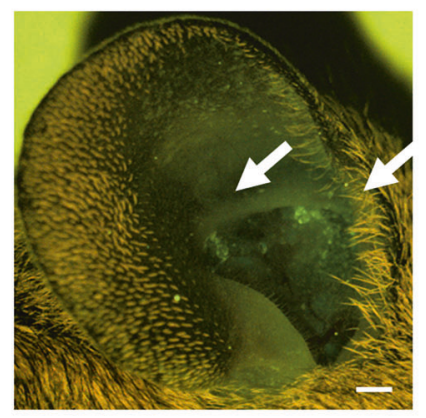

C

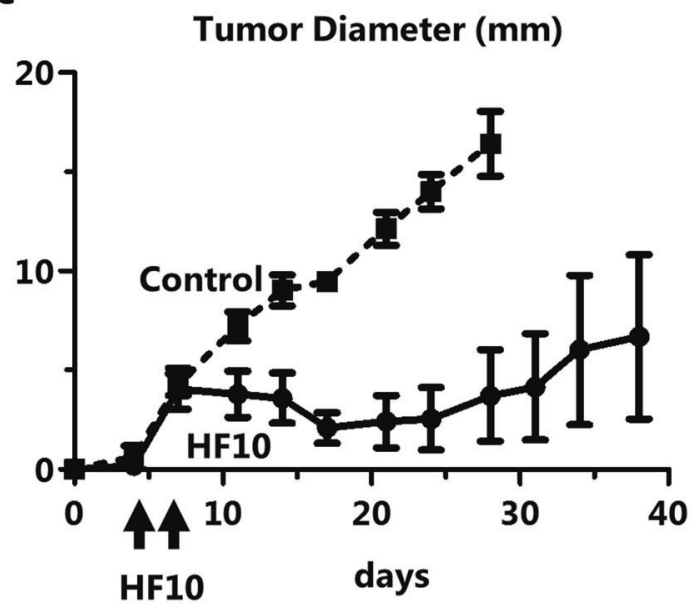

e

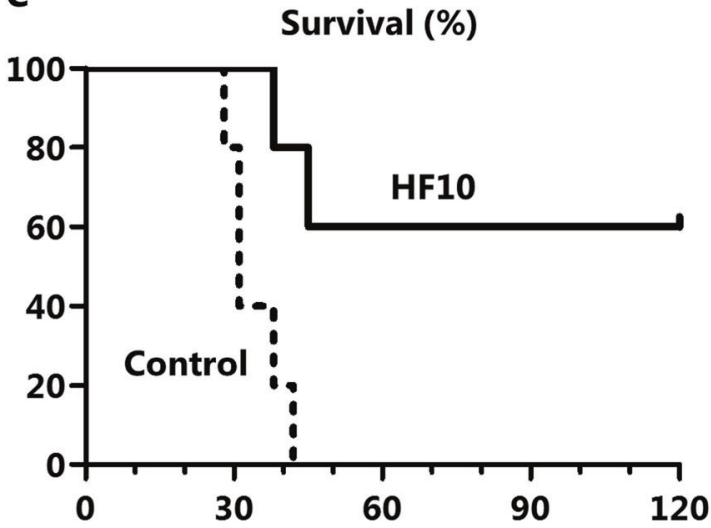

Fig. 4 HF10-suppressed SCC-VII ear tumor growth and induced antitumor immunity. a HF10-GFP was injected into SCC-VII ear tumors. GFP-positive cells were observed at $24 \mathrm{~h}$ after injection. The tumor is indicated by the arrow. Scale bars, $1 \mathrm{~mm}$. b Photographs of the mice after each treatment on day 17. The arrows indicate the ear tumors. c-e HF10 or PBS was intratumorally injected on days 4 and 7

recurrence [41]. Since primary and acquired resistance to conventional treatment are suspected reasons for tumor recurrence, the development of a new therapeutic agent is necessary. Most HNSCCs arise from the mucosa of the upper respiratory tract or superficial portion of the neck, b

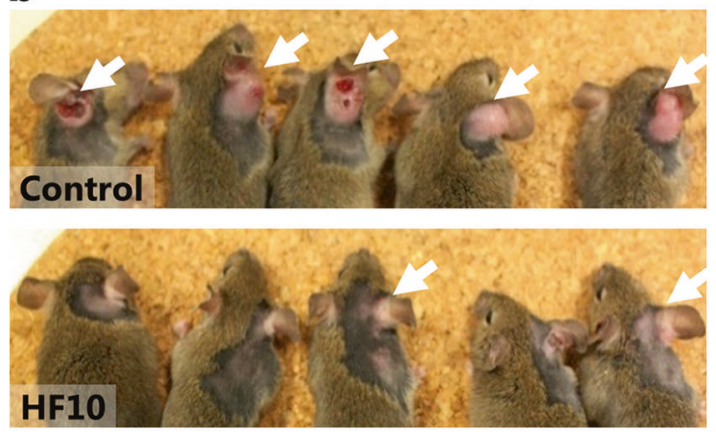

d

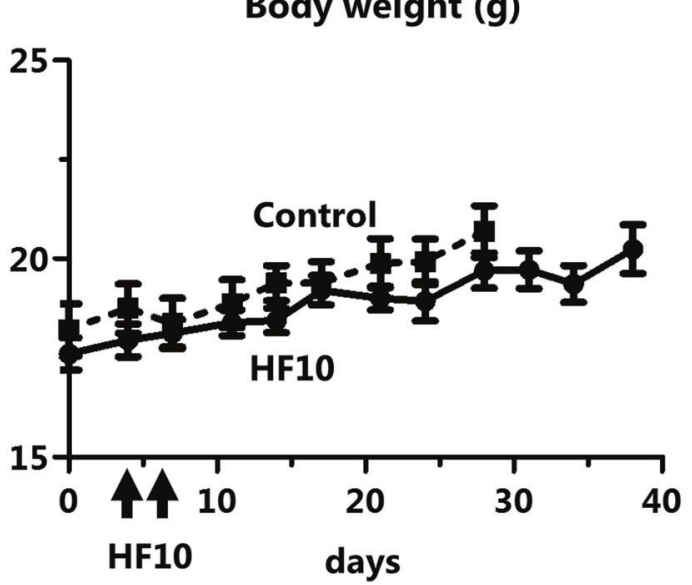

f

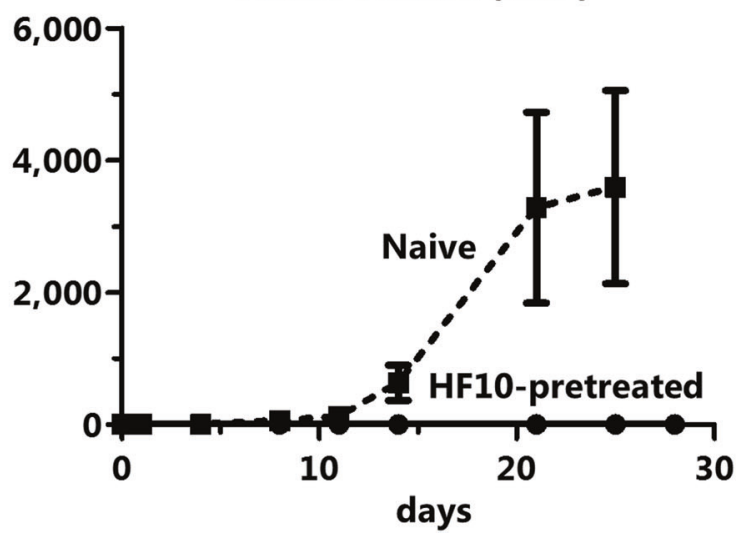

after tumor inoculation $(n=5)$. HF10 injection significantly suppressed tumor growth $(p<0.001)$ and significantly prolonged survival $(p<0.05)$. After HF10 treatment, 3 of 5 mice rejected their tumors and survived long-term. f SCC-VII cells were subcutaneously injected into naïve mice $(n=3)$ or the 3 mice that rejected their tumors after HF10 injection

which makes the tumors accessible for the injection of agents like oncolytic viruses. Oncolytic virotherapy is a promising anticancer therapy because it uses a distinct mechanism from other therapies to destroy cancer cells [42]. To date, several kinds of viruses have been assessed in 
a

H\&E

Anti-HSV

Anti-CD8

Anti-CD8 (peripheral)

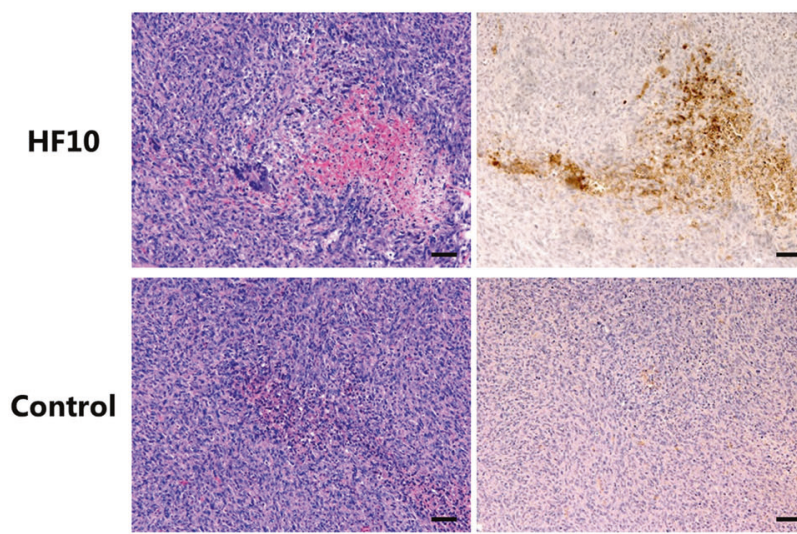

b
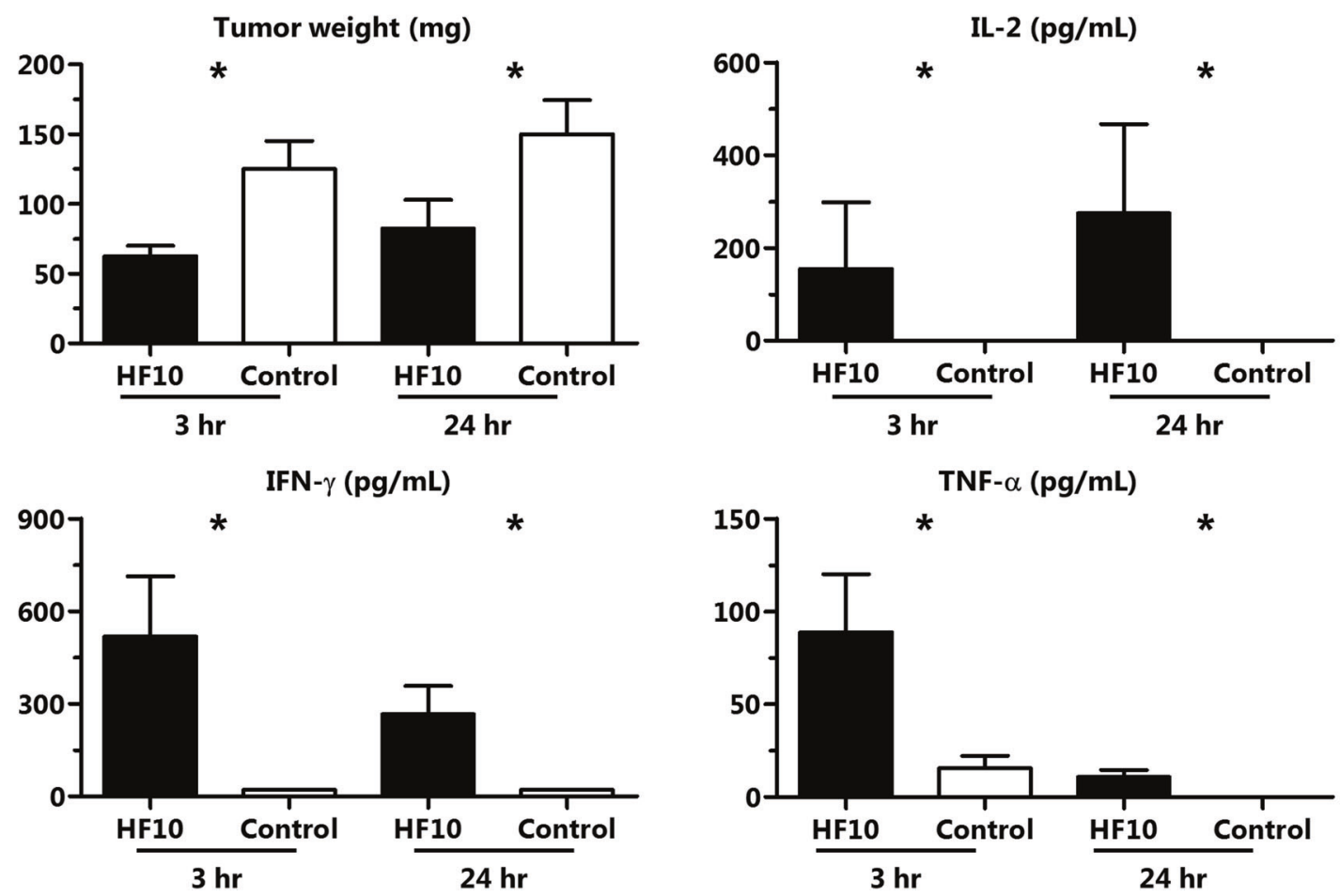

Fig. 5 HF10 injection induced tumor necrosis, $\mathrm{CD} 8^{+} \mathrm{T}$ cell accumulation in and around the tumor, and antitumor and immune-stimulatory cytokine production. a After HF10 injection into SCC-VII tumors, we performed H\&E, anti-HSV, and anti-CD8 staining. Scale bars,

$100 \mu \mathrm{m}$. b The SCC-VII tumors were removed at 3 and $24 \mathrm{~h}$ after the second injections of HF10 or PBS. We analyzed IL-2, IFN- $\gamma$, and TNF- $\alpha$ in the tumors $\left({ }^{*} p<0.05\right)$

clinical trials for the treatment of HNSCC, including HSV (HF10, seprehvir, and T-Vec), adenoviruses (ONYX-015 and NCT00006106), vaccinia viruses (GL-ONC1, NCT01584284, Pexa-Vec, and NCT00625456), coxsackievirus A21 (CAVATAK and NCT00832559), and fowlpox virus (TRICOM and NCT00021424). HF10 was isolated in our laboratory, and we have been exploring the potential use of HF10 as an oncolytic agent using various tumor models [28, 35, 36, 43-49]. In the current study, we investigated the oncolytic effects for HNSCCs and antitumor immunity induced by HF10 injection.

Previous studies of oncolytic viruses for the treatment of HNSCC used commercial cell lines. In the current study, we also used primary HNSCC cells from human hypopharyngeal cancer and mouse tongue cancer, which we suppose would have more similar characteristics of HNSCC tumors. HF10 replicated well and caused cell death in the primarycultured HNSCC cells as well as in HNSCC cell lines. In a prior study of ovarian cancer, tumorigenicity differed according to the site of implantation [50]. Therefore, we believe our ear tumor model to be more clinically relevant than flank models. The previous studies mentioned above 


\section{a}
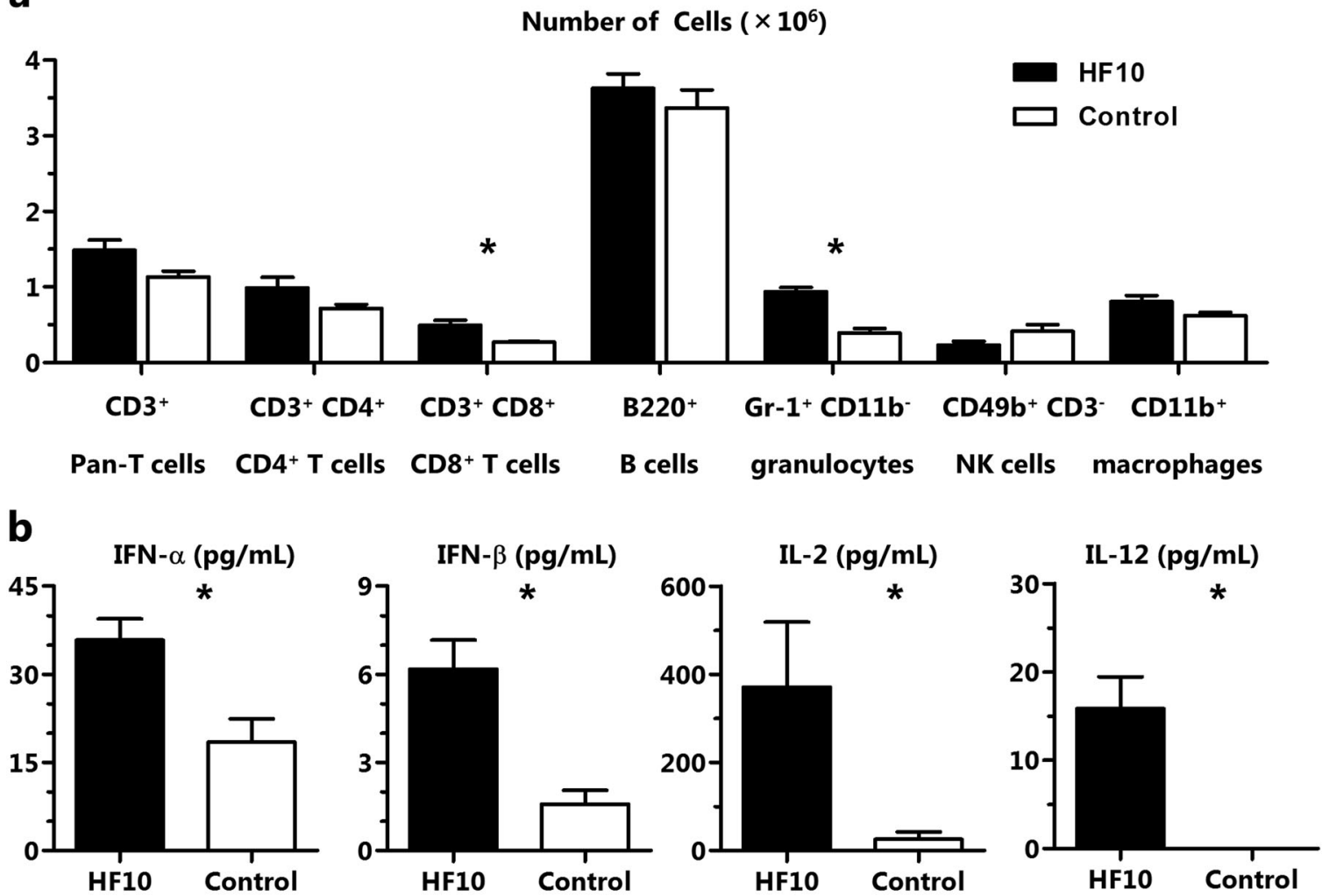

C

$\operatorname{IFN}-\gamma(p g / m L)$

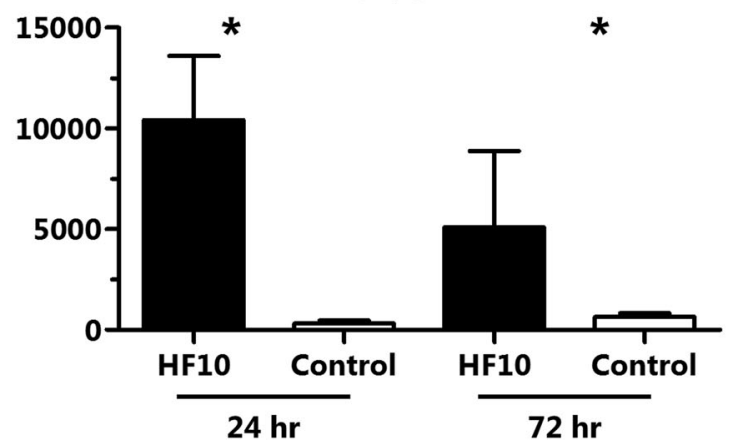

Fig. 6 HF10 treatment-induced $\mathrm{CD}^{+} \mathrm{T}$ cell and granulocyte accumulation in the spleen and the production of antitumor and immunestimulatory cytokines. a CD $45^{+}$leukocytes in the spleen were analyzed by flow cytometry for $\mathrm{CD}^{+}{ }^{+} \mathrm{CD}^{+} \mathrm{T}$ cells and $\mathrm{Gr}-1^{+} \mathrm{CD} 11 \mathrm{~b}^{-}$

used subcutaneous HNSCC tumors in the murine flank [1325]. In the current study, we established a more clinically relevant head and neck cancer model to investigate oncolytic effects in HNSCC tumors. By using the ear tumor model, we could observe the spread of HF10 within the tumors and suppression of tumor growth without any complications or weight loss. Taken together, HF10 selectively replicate in tumor cells and cause cell death without harming normal cells, which is in agreement with the concept of oncolytic virotherapy.

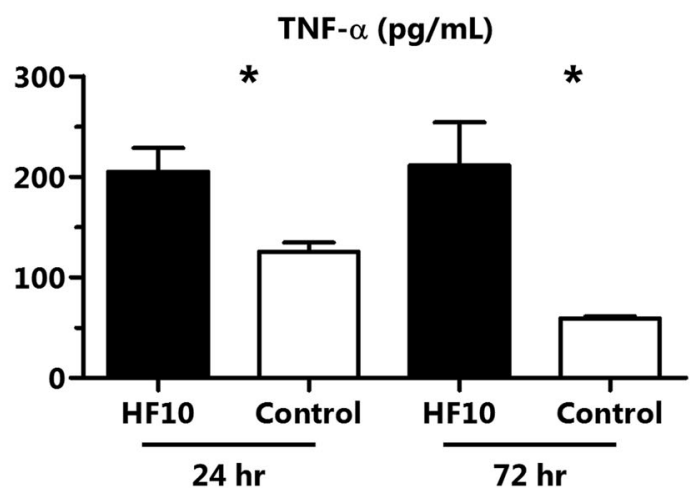

granulocytes in the spleen. $\mathbf{b}, \mathbf{c}$ The splenocytes were co-cultured with the SCC-VII cells for 24 and $72 \mathrm{~h}$. We analyzed the release of IFN- $\alpha$, IFN- $\beta$, IFN- $\gamma$, TNF- $\alpha$, IL- 2 , and IL-12 in the supernatants after $24 \mathrm{~h}$ $(* p<0.05)$ and IFN- $\gamma$ and TNF- $\alpha$ after $72 \mathrm{~h}(* p<0.05)$

Oncolytic viral infection also affects the immune system. Innate immune cells like macrophages and neutrophils remove virus-infected or dying tumor cells by phagocytosis [51]. After tumor destruction, tumor-associated antigen is released and adaptive immunity is activated. Macrophages and dendritic cells, so-called professional antigenpresenting cells (APCs), present foreign antigens to helper T cells using MHC class II molecules, and other cells except APCs can present foreign antigens to $\mathrm{CD}^{+}$CTLs using MHC class I molecules. Type 1 helper T (Th1) cells, but not 
type 2 helper T (Th2) cells, secrete IL-2, IFN- $\gamma$, and TNF- $\alpha$. IL-12 secreted by APCs stimulates IFN- $\gamma$ production by Th1 cells [52]. IFN- $\gamma$ and IL-2 activate macrophages and CTLs and inhibit Th2 cells. CTLs kill infected cells and produce cytokines, such as TNF- $\alpha$, IFN- $\gamma$, and lymphotoxin.

All mice that survived initial tumor challenge after HF10 treatment rejected tumor upon rechallenge, indicating that they had developed antitumor immunity. Therefore, we investigated the induction of antitumoral immunity. HF10 injection induced necrosis in the ear tumor where HSVinfected cells were observed and induced accumulation of $\mathrm{CD}^{+} \mathrm{T}$ cells. Tumor infiltration of $\mathrm{CD}^{+}$cytotoxic $\mathrm{T}$ cells is associated with longer disease-free survival and/or overall survival of patients with many different tumors, including head and neck cancers [53, 54]. CD4 $+\mathrm{T}$ cells were not found in or around the ear tumor. In our previous study, $\mathrm{CD} 4+\mathrm{T}$ cells were found in the peritumoral stroma [35], where T-cell migration occurs [55]. No peritumoral stroma was detected in the tumors formed by SCC-VII cells, which accounts for the lack of CD4+ T cells in or around the tumors.

The increased production of IFN- $\gamma$, TNF- $\alpha$, and IL-2 in the tumor was also indicative of immune activation. Then, we investigated the induction of systemic immunity. After HF10 treatment, granulocytes and $\mathrm{CD} 8^{+} \mathrm{T}$ cells accumulated in the spleen. When co-cultured with SCC-VII cells, the splenic cells released IFN- $\alpha$, IFN- $\beta$, IFN- $\gamma$, IL-2, IL-12, and TNF- $\alpha$. Recent preclinical studies have demonstrated the use of oncolytic HSVs as cancer vaccines [48, 56]. Based on our observations, HF10 injection activates antitumor immunity and protects against secondary tumor challenge, further supporting the potential of HSVs as in situ cancer vaccines.

Several clinical trials using oncolytic virus against HNSCCs are ongoing. Over a decade ago, intratumoral injection of two oncolytic HSVs (G207 and 1716) into glioblastomas decreased tumor size and prolonged patient survival [57, 58]. Ongoing clinical trials are assessing oncolytic viruses in combination with chemotherapeutic agents or immune checkpoint inhibitors to enhance the antitumor effect. Also, 'armed' oncolytic viruses, which produce, for example, GM-CSF and IL-12, are being evaluated in preclinical studies [59]. To show the benefit of oncolytic HSVs in the treatment of head and neck cancers, we must investigate methods to enhance the oncolytic effects of HSVs in mouse models.

In conclusion, this study showed that HF10 exerts an oncolytic effect on primary-cultured HNSCCs as well as HNSCC cell lines, and induced antitumoral immunity. The significance of this study lies in the fact that it is the first to focus on the oncolytic effect on HNSCC using primarycultured cells, and we investigated antitumor immunity.
However, this study was limited by our inability to evaluate oncolytic activity simultaneously against primary-cultured HNSCCs and antitumor immunity. Implantation of primarycultured tumors and hematopoietic cells from the same patient to immunodeficient mice can be used to evaluate oncolytic activity and antitumoral immunity against patientderived tumors; however, no study to date has addressed this issue. In future, we plan to evaluate oncolytic activity and the immune response using a mouse model prior to a clinical trial of this "precision medicine".

Acknowledgements We thank T. Kunogi for her technical support.

Funding This work was supported by a Grant-in-Aid for Young Scientists (15K20219) and Grant-in-Aid for Scientific Research (16K07166) from the Ministry of Education, Culture, Sports, Science, and Technology of Japan. This work was in part supported by Aichi Cancer Research Foundation.

\section{Compliance with ethical standards}

Conflict of interest The authors declare that they have no conflict of interest.

Publisher's note: Springer Nature remains neutral with regard to jurisdictional claims in published maps and institutional affiliations.

\section{References}

1. Leemans CR, Braakhuis BJ, Brakenhoff RH. The molecular biology of head and neck cancer. Nat Rev. 2011;11:9-22.

2. Siegel RL, Miller KD, Jemal A. Cancer Statistics, 2017. CA Cancer J Clin. 2017;67:7-30

3. Hori M, Matsuda T, Shibata A, Katanoda K, Sobue T, Nishimoto $\mathrm{H}$, et al. Cancer incidence and incidence rates in Japan in 2009: a study of 32 population-based cancer registries for the Monitoring of Cancer Incidence in Japan (MCIJ) project. Jpn J Clin Oncol. 2015;45:884-91.

4. Cattaneo R, Miest T, Shashkova EV, Barry MA. Reprogrammed viruses as cancer therapeutics: targeted, armed and shielded. Nat Rev Microbiol. 2008;6:529-40.

5. Pol J, Kroemer G, Galluzzi L. First oncolytic virus approved for melanoma immunotherapy. Oncoimmunology. 2016;5:e1115641.

6. Andtbacka RH, Kaufman HL, Collichio F, Amatruda T, Senzer N, Chesney J, et al. Talimogene laherparepvec improves durable response rate in patients with advanced melanoma. J Clin Oncol. 2015;33:2780-8.

7. Kaufman HL, Kim DW, DeRaffele G, Mitcham J, Coffin RS, Kim-Schulze S. Local and distant immunity induced by intralesional vaccination with an oncolytic herpes virus encoding GMCSF in patients with stage IIIc and IV melanoma. Ann Surg Oncol. 2010;17:718-30.

8. Watanabe D. Medical application of herpes simplex virus. J Dermatol Sci. 2010;57:75-82.

9. Fujimoto Y, Mizuno T, Sugiura S, Goshima F, Kohno S, Nakashima $\mathrm{T}$, et al. Intratumoral injection of herpes simplex virus HF10 in recurrent head and neck squamous cell carcinoma. Acta Otolaryngol. 2006;126:1115-7.

10. Mace AT, Ganly I, Soutar DS, Brown SM. Potential for efficacy of the oncolytic Herpes simplex virus 1716 in patients with oral squamous cell carcinoma. Head Neck. 2008;30:1045-51. 
11. Harrington KJ, Hingorani M, Tanay MA, Hickey J, Bhide SA, Clarke PM, et al. Phase I/II study of oncolytic HSV GM-CSF in combination with radiotherapy and cisplatin in untreated stage III/ IV squamous cell cancer of the head and neck. Clin Cancer Res. 2010;16:4005-15.

12. Eissa IR, Naoe Y, Bustos-Villalobos I, Ichinose T, Tanaka M, Zhiwen W, et al. Genomic signature of the natural oncolytic herpes simplex virus HF10 and its therapeutic role in preclinical and clinical trials. Front Oncol. 2017;7:149.

13. Mace AT, Harrow SJ, Ganly I, Brown SM. Cytotoxic effects of the oncolytic herpes simplex virus HSV1716 alone and in combination with cisplatin in head and neck squamous cell carcinoma. Acta Otolaryngol. 2007;127:880-7.

14. Takaoka H, Takahashi G, Ogawa F, Imai T, Iwai S, Yura Y. A novel fusogenic herpes simplex virus for oncolytic virotherapy of squamous cell carcinoma. Virol J. 2011;8:294.

15. Naito S, Obayashi S, Sumi T, Iwai S, Nakazawa M, Ikuta K, et al. Enhancement of antitumor activity of herpes simplex virus gamma (1)34.5-deficient mutant for oral squamous cell carcinoma cells by hexamethylene bisacetamide. Cancer Gene Ther. 2006;13:780-91.

16. Carew JF, Kooby DA, Halterman MW, Federoff HJ, Fong Y. Selective infection and cytolysis of human head and neck squamous cell carcinoma with sparing of normal mucosa by a cytotoxic herpes simplex virus type 1 (G207). Hum Gene Ther. 1999;10:1599-606.

17. Price DL, Lin SF, Han Z, Simpson G, Coffin RS, Wong J, et al. Oncolysis using herpes simplex virus type 1 engineered to express cytosine deaminase and a fusogenic glycoprotein for head and neck squamous cell carcinoma. Arch Otolaryngol Head Neck Surg. 2010;136:151-8.

18. Yoo JY, Yu JG, Kaka A, Pan Q, Kumar P, Kumar B, et al. ATN224 enhances antitumor efficacy of oncolytic herpes virus against both local and metastatic head and neck squamous cell carcinoma. Mol Ther Oncolytics. 2015;2:15008.

19. Kim SH, Wong RJ, Kooby DA, Carew JF, Adusumilli PS, Patel $\mathrm{SG}$, et al. Combination of mutated herpes simplex virus type 1 (G207 virus) with radiation for the treatment of squamous cell carcinoma of the head and neck. Eur J Cancer. 2005;41:313-22.

20. Yu Z, Adusumilli PS, Eisenberg DP, Darr E, Ghossein RA, Li S, et al. Nectin-1 expression by squamous cell carcinoma is a predictor of herpes oncolytic sensitivity. Mol Ther. 2007;15:103-13.

21. Yu Z, Li S, Huang YY, Fong Y, Wong RJ. Calcium depletion enhances nectin-1 expression and herpes oncolytic therapy of squamous cell carcinoma. Cancer Gene Ther. 2007;14:738-47.

22. Meshii N, Takahashi G, Okunaga S, Hamada M, Iwai S, Takasu A, et al. Enhancement of systemic tumor immunity for squamous cell carcinoma cells by an oncolytic herpes simplex virus. Cancer Gene Ther. 2013;20:493-8.

23. Wong RJ, Joe JK, Kim SH, Shah JP, Horsburgh B, Fong Y. Oncolytic herpesvirus effectively treats murine squamous cell carcinoma and spreads by natural lymphatics to treat sites of lymphatic metastases. Hum Gene Ther. 2002;13:1213-23.

24. Wong RJ, Kim SH, Joe JK, Shah JP, Johnson PA, Fong Y. Effective treatment of head and neck squamous cell carcinoma by an oncolytic herpes simplex virus. J Am Coll Surg. 2001;193:12-21.

25. Wong RJ, Patel SG, Kim S, DeMatteo RP, Malhotra S, Bennett JJ, et al. Cytokine gene transfer enhances herpes oncolytic therapy in murine squamous cell carcinoma. Hum Gene Ther. 2001;12:253-65.

26. Takakuwa H, Goshima F, Nozawa N, Yoshikawa T, Kimata H, Nakao A, et al. Oncolytic viral therapy using a spontaneously generated herpes simplex virus type 1 variant for disseminated peritoneal tumor in immunocompetent mice. Arch Virol. 2003;148:813-25.
27. Ushijima Y, Luo C, Goshima F, Yamauchi Y, Kimura H, Nishiyama Y. Determination and analysis of the DNA sequence of highly attenuated herpes simplex virus type 1 mutant HF10, a potential oncolytic virus. Microbes Infect. 2007;9:142-9.

28. Fujiwara S, Nawa A, Luo C, Kamakura M, Goshima F, Kondo C, et al. Carrier cell-based delivery of replication-competent HSV-1 mutants enhances antitumor effect for ovarian cancer. Cancer Gene Ther. 2011;18:77-86.

29. Descamps G, Wattiez R, Saussez S. Proteomic study of HPVpositive head and neck cancers: preliminary results. Biomed Res Int. 2014;2014:430906.

30. Sasai K, Fushiki M, Yukawa Y, Suyama S, Iwai H, Shibamoto Y, et al. In vivo radiosensitizing activity of a new fluorinated hypoxic cell radiosensitizer, KU-2285, in combination with radiation dose fractionation. Int J Radiat Oncol Biol Phys. 1991;21:1231-4.

31. Shibata T, Shibamoto Y, Oya N, Sasai K, Murata R, Ishigaki T, et al. Comparison of radiosensitizing effect of KU-2285 and SR2508 at low drug concentrations and doses. Int J Radiat Oncol Biol Phys. 1994;29:587-90.

32. Kimura H, Morita M, Yabuta Y, Kuzushima K, Kato K, Kojima $\mathrm{S}$, et al. Quantitative analysis of Epstein-Barr virus load by using a real-time PCR assay. J Clin Microbiol. 1999;37:132-6.

33. Esaki S, Goshima F, Katsumi S, Watanabe D, Ozaki N, Murakami S, et al. Apoptosis induction after herpes simplex virus infection differs according to cell type in vivo. Arch Virol. 2010;155:1235-45.

34. Esaki S, Goshima F, Kimura H, Ikeda S, Katsumi S, Kabaya K, et al. Auditory and vestibular defects induced by experimental labyrinthitis following herpes simplex virus in mice. Acta Otolaryngol. 2011;131:684-91.

35. Goshima F, Esaki S, Luo C, Kamakura M, Kimura H, Nishiyama Y. Oncolytic viral therapy with a combination of HF10, a herpes simplex virus type 1 variant and granulocyte-macrophage colonystimulating factor for murine ovarian cancer. Int $\mathrm{J}$ Cancer. 2014; 134:2865-77.

36. Esaki S, Goshima F, Kimura H, Murakami S, Nishiyama Y. Enhanced antitumoral activity of oncolytic herpes simplex virus with gemcitabine using colorectal tumor models. Int $\mathrm{J}$ Cancer. 2013;132:1592-601.

37. Hirst DG, Brown JM, Hazlehurst JL. Enhancement of CCNU cytotoxicity by misonidazole: possible therapeutic gain. $\mathrm{Br} \mathrm{J}$ Cancer. 1982;46:109-16.

38. Mery B, Rancoule C, Guy JB, Espenel S, Wozny AS, BattistonMontagne $\mathrm{P}$, et al. Preclinical models in HNSCC: a comprehensive review. Oral Oncol. 2017;65:51-6.

39. Mognetti B, Di Carlo F, Berta GN. Animal models in oral cancer research. Oral Oncol. 2006;42:448-60.

40. Schoop RA, Noteborn MH, Baatenburg deJongRJ. A mouse model for oral squamous cell carcinoma. J Mol Histol. 2009;40:177-81.

41. Seiwert TY, Cohen EE. State-of-the-art management of locally advanced head and neck cancer. Br J Cancer. 2005;92:1341-8.

42. Chiocca EA. Oncolytic viruses. Nat Rev. 2002;2:938-50.

43. Kimata H, Takakuwa H, Goshima F, Teshigahara O, Nakao A, Kurata $\mathrm{T}$, et al. Effective treatment of disseminated peritoneal colon cancer with new replication-competent herpes simplex viruses. Hepatoastroenterology. 2003;50:961-6.

44. Kohno S, Luo C, Goshima F, Nishiyama Y, Sata T, Ono Y. Herpes simplex virus type 1 mutant HF10 oncolytic viral therapy for bladder cancer. Urology. 2005;66:1116-21.

45. Kohno SI, Luo C, Nawa A, Fujimoto Y, Watanabe D, Goshima F, et al. Oncolytic virotherapy with an HSV amplicon vector expressing granulocyte-macrophage colony-stimulating factor using the replication-competent HSV type 1 mutant HF10 as a helper virus. Cancer Gene Ther. 2007;14:918-26.

46. Shimoyama S, Goshima F, Teshigahara O, Kasuya H, Kodera Y, Nakao A, et al. Enhanced efficacy of herpes simplex virus mutant 
HF10 combined with paclitaxel in peritoneal cancer dissemination models. Hepatogastroenterology. 2007;54:1038-42.

47. Teshigahara O, Goshima F, Takao K, Kohno S, Kimata H, Nakao A, et al. Oncolytic viral therapy for breast cancer with herpes simplex virus type 1 mutant HF 10. J Surg Oncol. 2004;85:42-7.

48. Watanabe D, Goshima F, Mori I, Tamada Y, Matsumoto Y, Nishiyama Y. Oncolytic virotherapy for malignant melanoma with herpes simplex virus type 1 mutant HF10. J Dermatol Sci. 2008;50:185-96.

49. Tanaka R, Goshima F, Esaki S, Sato Y, Murata T, Nishiyama Y, et al. The efficacy of combination therapy with oncolytic herpes simplex virus HF10 and dacarbazine in a mouse melanoma model. Am J Cancer Res. 2017;7:1693-703.

50. Hernandez L, Kim MK, Lyle LT, Bunch KP, House CD, Ning F, et al. Characterization of ovarian cancer cell lines as in vivo models for preclinical studies. Gynecol Oncol. 2016;142:332-40.

51. Aderem A, Underhill DM. Mechanisms of phagocytosis in macrophages. Annu Rev Immunol. 1999;17:593-623.

52. Mosmann TR, Sad S. The expanding universe of T-cell subsets: Th1, Th2 and more. Immunol Today. 1996;17:138-46.

53. Fridman WH, Pages F, Sautes-Fridman C, Galon J. The immune contexture in human tumours: impact on clinical outcome. Nat Rev. 2012;12:298-306.
54. Czystowska M, Gooding W, Szczepanski MJ, Lopez-Abaitero A, Ferris RL, Johnson JT, et al. The immune signature of CD8(+) CCR7 $(+) \mathrm{T}$ cells in the peripheral circulation associates with disease recurrence in patients with HNSCC. Clin Cancer Res. 2013;19:889-99.

55. Ogawa M, Umehara K, Yu WG, Uekusa Y, Nakajima C, Tsujimura $\mathrm{T}$, et al. A critical role for a peritumoral stromal reaction in the induction of T-cell migration responsible for interleukin-12induced tumor regression. Cancer Res. 1999;59:1531-8.

56. Toda M, Rabkin SD, Kojima H, Martuza RL. Herpes simplex virus as an in situ cancer vaccine for the induction of specific antitumor immunity. Hum Gene Ther. 1999;10:385-93.

57. Markert JM, Medlock MD, Rabkin SD, Gillespie GY, Todo T, Hunter WD, et al. Conditionally replicating herpes simplex virus mutant, G207 for the treatment of malignant glioma: results of a phase I trial. Gene Ther. 2000;7:867-74.

58. Rampling R, Cruickshank G, Papanastassiou V, Nicoll J, Hadley D, Brennan D, et al. Toxicity evaluation of replicationcompetent herpes simplex virus (ICP 34.5 null mutant 1716) in patients with recurrent malignant glioma. Gene Ther. 2000;7:859-66.

59. Fukuhara H, Ino $\mathrm{Y}$, Todo T. Oncolytic virus therapy: a new era of cancer treatment at dawn. Cancer Sci. 2016;107:1373-9. 